\title{
The Role of Empathy in the Learning Process and Its Fruitful Outcomes: A Comparative Study
}

\author{
Adil Kutlu \\ A lecturer at Beder University, a PhD candidate in European University of Tirana \\ e-mail: akutlu@beder.edu.al \\ Lokman Coskun \\ A lecturer at Beder University, a PhD candidate in European University of Tirana \\ e-mail: Icoskun@beder.edu.al
}

Doi:10.5901/jesr.2014.v4n2p203

\section{Abstract}

The aim of this study is to identify the role of empathy in learning process and to make students get involved in it and obtain fruitful outcomes in this direction. The qualitative method was used in this study to find out due data for explaining the positive effects of empathy for better learning. This study emphasizes the importance of empathy and its influence for making the learning process fruitful through comparing the explanations and views of Carl Rogers and the Prophet Muhammad. Actually, when the teacher approaches the students with empathy, he teaches the students not only how to use empathy towards other people but also they demonstrate empathy towards animals. The data were collected from the written views of Carl Rogers and the Prophet Muhammad's approach in relation with empathy. The limitation is that we could not make any questionnaire or interviews. If those were done with some professors the reliable data were collected. The results explain that the teachers should approach the students like mother and father while teaching. Thus, this approach will make students learn easily and also make the students motivation high and better towards learning.

Keywords: Empathy, learning process, outcomes, approach, positive effect

\section{Introduction}

Nowadays, the methods used in education are changing rapidly according to the circumstances in relation with the activities of learning and teaching in a qualified way in order to reach the success. Every discipline in science has significance how and which methods should be used in its respective field (Şeker, 2010, p.91).

Generally, during the education term the methods are expressed as a facilitator in order to solve a problem, to conclude an experiment, and a way to be followed how to learn or teach a particular topic. So, the method that is selected plays an important role in fulfilling the aim and gaining the behaviors we want (Sevindik, 2010,. p. 3).

The aim of education is to train people who know how to reach the information, how to use the information that he learned and to produce new information by using this information and also to use it in daily life. Another topic that we should emphasize is the people that carry out the education. School program, tools and supplies, school buildings are very important in developing the education, but the most important thing is teaching. So, to achieve the goal, teachers must be qualified in their subject and should know very well which method to use and how to use (Alıcıgüzel, 1999, p.123).

Teacher should take into consideration the students' logical and emotional behaviors, mental evolution level and motivation level to be successful in selecting the right method. And, he should use the results from the researches done previously. Actually, to have a good relation and communication with students can be done, just with a suitable method relevant to the content.

In this study, we state and give examples about the empathy method developed by Carl Rogers that is widely used in education, and how the Prophet Muhammad (P.B.U.H) used this method to reach the perfection in morality for the people who follow him, and also just to give some new ideas to teachers.

Teaching profession is as old as the profession of the prophet hood, as it started with the first human being Prophet Adam and continued with other prophets. Knowing all human dispositions, Prophets have used all effective 
methods to guide their people in the right way.

\section{Literature Review}

We can define empathy as the action of putting oneself in one's place, to understand his emotions, his thoughts in the right way and up to today it has been defined by a lot of researchers (Dökmen, 2001, p.135).

According to Tuncay and II , Ancient Greek Philosophers have articulated their understanding of empathy as the active joining with the others emotional and spiritual experience that comes from word "empatheia". Relay on its linguistic roots on Ancient Greek the concept of empathy is basically is scientific accumulation of $19^{\text {th }}$ and $20^{\text {th }}$ century (Tuncay and II, 2009, p.40).

Dökmen says that the German psychologist Teodor Lipps in 1897 defines the concept of "einfuhlung" reflection of a person in an object, and feeling himself in it, and in this way taking that object inside and understanding it (Dökmen, 2001, p. 339-340).

According to Anar einfuhlen; "to feel the feelings of the person you have before you" is used firstly from the German Philosopher J. G. Herder. Declaring that human gaining the skill of penetrating to nature consciously, he adds that empathy has created a mystic union between human being and nature (Anar, 2013, p. 27).

G.B. Hunsdahl has an article related to development of history and source of Einfuhlung. He identified that the term empathy has been used for the first time in English by Titchener. According to Hunsdahl, Titchener has translated the word "empathia" from Greek to English in "empathy" in 1909 (Anar, 2013, p. 27).

Hofman defines empathy as an ability of putting yourself in someone's shoes, feeling what he feels. According to Adler; empathy is looking through the eyes of others, hearing through the ears of others and feeling through the heart of others (Demir, 2012, p. 108)

Batson and his friends draw attention to relevant scientific publications that have been done in empathy between the years 1950-1970 by many researchers through using different definitions. There is absolutely a consistency between the definitions which are highlighted. The first name that comes to our mind when we think about empathy is Carl Rogers. He is known about his researches that he has done in Communication empathy in psychotherapy. The definition that Rogers puts forward is empathy in 1970 which is being used still in nowadays (Dökmen, 2001. P.135). According to Carl Rogers 'empathy is "putting yourself into someone's position, understanding his thoughts and feelings" (Tuncay and III, 2009, p. 42).

\section{Discussion}

The definition of empathy that we use today has been reached as a result of changes in many years. Before Rogers, empathy has been discussed in very different ways. One of first users of this concept is the German psychologist Tpeodor Lipps, he has defined the word "einfuhlung" in 1897 " to reflect yourself into an object, to feel yourself in it and in this way you understand it better". In his later studies, he says that among objects "einfühlung" may arise even in perception of human. And, when we come to 1909 the word "einfuhlung" that is in German is translated from the ancient Greek word "empatheia" to English as "empathy" from Titchener (Dökmen, 2001, p. 339-340).

Batson and his friends take our attention that if we compare relevant scientific publications of empathy in different years, it is defined in different ways as well, and there isn't consistency between the definitions. When we examine this claim about the definition of empathy in publications over the years, now it is seen that there are three basic stages. We can express this stages as follows: The empathy from the beginning until 1950's, it has been taken as a qualified scientific concept, "measurement of empathy" has measured how people perceive each other's personality traits.

In 1960's it has been highlighted both the scientific dimension and emotional dimension of empathy. In these years as "empathy" was accepted as "to put you in someone else". In 1970's the third stage started. Comparing this period with 1960's empathy has been used in narrower rate, to understand ones emotions and to convey it to him was called "empathy" (Dökmen, 2001, p. 340-341).

Rogers gains an indispensable place to counseling psychology in clinic field empathy, the development of social psychology, counseling and school psychology and communication have been done a lot of studies, and there is a large accumulation of knowledge for this topic (Dökmen, 1987, p. 185; \& 2001, p. 134).

Researchers have shown that empathy apparently made a positive contribution in interpersonal relationships and social cohesion, not only in psychology but also it can be used in all areas in our daily life. These individuals who have these skills understand the thoughts and feelings of interlocutors correctly. Empathy is known as a facilitator in 
interpersonal relationships, so it is used in a variety of professionals in order to improve their empathic skills in training that they provide. One of the professions that is provided this training is teaching (Ercoşkun, et. al., 2006, p. 208).

Teaching is one of the professions where interpersonal relationships are in an intense way. So, it is a very important relation between teachers and students. In one way showing empathy, teachers become a good model to students, and it provides to understand them better. In this case, the good teacher-student relationship affects students to get positive achievements. In some researches, Dökmen has conducted that in classes the teachers show high-level understanding and empathy, and motivation of students and also the achievement levels are higher (Ercoşkun, et. al., 2006, p. 209).

Again we learn from the researches that empathy doesn't have a positive impact only in daily life but also it affects positively the moral development in students. If someone harms something we can draw their attention to the damage they caused. If we can teach them how to put themselves in

The aim of education is to train perfect people and this mission is on the shoulders of teachers partially. Prophecy teaching profession as being so old, firstly it started with Prophet Adam and continued with and followed by the other prophets.

Knowing the human nature in perfect way, prophets were sent to the tribes (people) regarded with the characteristics of that tribe to fulfill their duties of teaching, to convey their Ummah (people) to the right way, prophets used all the effective ways of teaching. Firstly, they lived in their life's as it was reported from God as original and after that, they taught the others. And, when they were teaching to people, they used the right method concerning their ability of understanding.

Developed by Carl Rogers the method of empathy is widely used in education. The prophet Muhammad (P.B.U.H) was sent to train people and address them the moral and humanitarian aspects through the method of empathy. In Quran is reported as Prophet Muhammad was teaching as follows: "Just as We sent to you a messenger from among you, who recites Our revelations to you, and purifies you, and teaches you the Book and wisdom, and teaches you what you did not know" (Al-Baqarah 2/151).

Hz. Muhammad (P.B.U.H) has left no gaps in education with the training style that he used. History testifies his success with the personalities that he raised, where they become from people that buried their own daughters alive to sensitive people that they would not harm even an ant (Bozali, 2014).

Hz. Muhammad (P.B.U.H) is the best person to be taken as exemplary in Islam. Having also the highest morality The Prophet Muhammad (P.B.U.H), he trained his people theough the behaviors by living it, he was a proof of the highest morality living. To build a society of people with good virtuous, Hz. Muhammad (P.B.U.H) has lived an emphatic life, and has given the examples of empathy during his whole life (Çetin, 2010, p. 33).

If we examine the Hadith sources, we can find Hadith that speaks about particular period but also there are a lot of hadith that speak about empathy in general to whole humanity(people). In this context, the definition of Carl Rogers relevant to the three basic elements that constitute to empathy, would be the right place to give some examples of words, behavior's and applications from the life of Prophet Muhammad (P.B.U.H).

According to Dokmen; in definition of Rogers "Putting oneself instead of a person and looking through events from his perspective, understanding that persons feelings and thoughts correctly, feel it and convey this process to him" we will see that there are three main stages (Dökmen, 2001, p.135).

Firstly: If a person wants to understand his interlocutor, to detect events like him should put itself in his shoes and should look through things from his perspective (Dökmen, 2001, p. 135).

Signing at this point in a hadith Prophet Muhammad (P.B.U.H) associates empathy with the iman(faith), he says: "If one of you doesn't desire for his brother what he desires for himself would have not believed" (Budak and Çetinkaya, 2008, p. 81)

Describing the point of view and nature of Islam for this world, and to increase the positively the vitality of interpersonal communication emphasizes the need of thinking others. Here, it draws a portrait of individuals with good morals and sensitive that doesn't want for his brother what he doesn't want for himself, and asks for his brother what he asks for himself. As principle of this hadith, it includes a warning, it focuses attention to the negative effects that selfishness will do to a person's faith (Altun, 2006, p. 100-101).

Secondly: in order to be deemed to have empathy you should understand your partners thoughts and feelings correctly. Scientific and emotional, empathy has two basic components. It's not enough only to understand someone's feelings and thoughts. Understanding what your interlocutor think is qualified cognitive activity and feeling the same emotional is a sensing quality activity (Dökmen, 2001, p.136).

As in all religions, Islam also commands individual consciousness which includes respect to God, through making 
people conscious with the aid of commands and prohibitions. The prophet Muhammad (P.B.U.H) also explained the benefits and harms through persuasion and make people see the wisdom of the orders and as wel as prohibitions.

While doing that empathy was used as an effective training method. Empathy can establish the right person, he does not like the fact that things will not be welcomed by others has shown that we can understand in practice (Çetin, 2010, p.34)

A teenager named Culeybib, one day the Messenger of Allah came , " allow me to commit adultery , because I will not be able to endure," he said. The reaction was found there differently by the prophet.

The prophet as he is the embodiment of compassion and mercy let the young man sit down nearby him and listens to him very carefully. He was fascinated with the breath of the prophet smelling like heaven. The prophet asked the young man:

" Would you like such a thing done with your mother?

- May my father be sacrificed for you, Oh Messenger of Allah, I would not.

- No man does not want done such a thing to his mother.

- Would you like some one to make it to your daugther such a thing?

- I never would like such as thing, may my soul be sacrificed for you.

- No man does not want such a thing for their daugther.

- Would you like it with your aunt such a thing?

- No, I do not want .

- No one at home with her daughter, sisters , aunts , and wants to do adultery ... (Musnad , 5/ 256, 257)" (Çetin, 2010,

p. 34-35).

Our Prophet (P.B.U.H) lets a young man speak even about unlawful things, later on, the prophet tries to convince him not to do this unlawful behavior. While he was listening to the young man, he was making think about the same situation, in case his beloved ones are in the same situation, therefore he was making him think about possible results through empathy. Very soon, he understands the feelings of the young man, then channelize him to close friend to solve his marrige problem, because with the help lawful way there is possibility to pleasure from life.

Third: Empathy is the way to understand the feelings of the person, then to give the message that you understand his feeling throuh words and behaviors. Even if you understand fully, but you did not explaine it how you understand, the process is not finished yet (Dökmen, 2001, p.137).

Lack of empathy will cause self-centered lifestyle that is unwelcome in today's society, even it happened in the past. The prophet Muhammad (P.B.U.H) inspires the people how to be sensitive to the people around him and to teach them the responsibilities of togetherness and also living together.

The prophet Muhammad (P.B.U.H) said: " A neighbor sleeps with hunger, while you sleep with full stomach, that is not one of us." through which he admonishes the insensetive people a bit harshly and the prophet makes awareness about hunger and puts responsibility on neighbourhood towards people in their situations (Altun, 2006, p. 103).

\section{Conlusion}

Empathy teaches the teachers, parents, and the other people the way how to feel the other people feel in the same fashion. Because, it is not possible to make people have same feelings and same experiences in the lives, but it is possible to put yourself in others shoes to feel what they feel. Actually, putting yourself in on place is the behavour human being not animals.

If teachers develop a better way how to feel the students feel, then they can teach better than before. If the people do not put themselves in somebody' s place, there is possibility for to be selfish for them.

Empathy contributes too much to education due to its positive results seen teaching and training activities in educational environment and told by many teachers and trainers. Teahers shoud find various ways to develop empathy for many reasons, so that they can make their students think about the others. It is not possible to put everything into practice but empathy makes itself felt everywhere.

Therefore, this study suggests that feeling is a best way for beginning to learn in many things. Especially, empathy is likely to work in classroom environmnet, since the teachers cannot take their respective students everywhere to teach, but through developing the way empathy the students put themselves in the place of other, and as a result they start learning. 


\section{Reference}

Alıcıgüzel, İ. (1999). Çağdaş okulda Eğitim ve Öğretim. İstanbul : Sistem yayıncılık.

Altun, M. (2006). İslam Eğitim Geleneğinin Temel Kaynaklarında Empatik Yaklaşım. Unpublished Master's Thesis. Ankara: Ankara Üniversitesi SBE.

Anar, T. (2013). Edebiyat Eserlerini Anlamak Ve Yorumlamak İçin Farklı Bir Yöntem: Einfühlung Teorisi, Türk Dili ve Edebiyatı Dergisi, Cilt/Sayı: 48,2013, pp. 23-46

Bozali, B. (t.y )(Bozali, Betül. Muallim Peygamber, http://www.siyerinebi.com/muallim- peygamber.html (April 12, 2014).

Budak, A. and Çetinkaya, Ö. (Ed.). (2008). Riyazu's Salihin-Muhtasar / İmam Nevevî. İzmir: Işık Yayınları Muhyiddin Yahya b. Seref, Riyazü's-Salihîn Tercümesi, Çev. H.Hüsnü

Çetin, Ü. F. (2010) Ortaöğretim Düzeyi Gençlerde Dindarlik-Empati Illişkisi (Isparta Örneği). Unpublished Master's Thesis. Isparta : Süleyman Demirel Üniversitesi SBE.

Demir, M. K., (2012). Sınıf Öğretmeni Adaylarının Empati Becerilerinin İncelenmesi (Analyzing Empathy Skills Of Primary School Teacher Candidates). Buca Eğitim Fakültesi Dergisi, 33, pp. 107-1218-Dökmen, Ü. (1987). Empati Kurma Becerisi ile Sosyometrik Statü Arasındaki İlişki, Ankara Üniversitesi Eğitim Bilimleri Fakültesi Dergisi, 20 (1-2), pp. 183-207

Dökmen, Ü. (2001). İletişim Çatışmaları ve Empati. 17. Baskı. İstanbul: Sistem Yayıncılık.

Ercoşkun, M. H., Dilekmen, M., Ada, Ş., Nalçaci, A. (2006). Sınıf Öğretmenliği Öğrencilerinin Empatik Becerilerinin Bireysel Değişkenler Açısından İncelenmesi. Kazım Karabekir Eğitim Fakültesi Dergisi, Yıl:2006 Sayı: 13, pp. 207-217

Sevindik, T. (2010). Özel Öğretim Yöntemleri Ders Notları. Yıldız Teknik Üniversitesi Eğitim

Fakültesi,http://www.yarbis1.yildiz.edu.tr/web/userAnnouncementsFiles/dosyab6b0482868ab2edc90ł2394f4480ef51.pdf, (April 14, 2014)

Şeker, K. (2010). Tarih ve Sosyal Bilgiler Öğretiminde Empati. Mehmet Akif Ersoy Üniversitesi Sosyal Bilimler Enstitüsü Dergisi,Yıl: 2 , Sayı: 2, pp. 91-105

Tuncay, T. and III, S. (2009). Sosyal Hizmet Uygulamasında Empatiyi Yeniden Düşünmek (Rethinking Empathy in Social Work Practice). Toplum ve Sosyal Hizmet, Cilt 20, Sayı 2, pp.39-56 